GEOLOGICA BALCANICA 50 (2), Sofia, August 2021, pp. 35-46.

\title{
Groundwater chemistry: a case study of the Mesta River Basin
}

\author{
Tanya Vasileva ${ }^{1}$, Dimitar Sholev ${ }^{2}$ \\ ${ }^{1}$ Geological Institute, Bulgarian Academy of Sciences, Acad. G. Bonchev Str., Bl. 24, 1113 Sofia, Bulgaria; \\ e-mail: tanyav@geology.bas.bg \\ ${ }^{2}$ Laboratory of Telematics, Bulgarian Academy of Sciences, Acad. G. Bonchev Str., Bl. 8, 1113 Sofia, Bulgaria; \\ e-mail: teacher@cc.bas.bg
}

(Received: 25 May 2021; accepted in revised form: 05 July 2021)

\begin{abstract}
The present study describes the hydrochemistry of ground waters found in the Mesta River Basin, located in the south-western part of Bulgaria. The groundwater's composition can be expressed as follows: $\mathrm{Ca}^{2+}>\mathrm{Na}^{+}>\mathrm{Mg}^{2+}>\mathrm{K}^{+} ; \mathrm{Ca}^{2+}>\mathrm{Mg}^{2+}>\mathrm{Na}^{+}>\mathrm{K}^{+}$in equivalent units for the cations, and $\mathrm{HCO}_{3}{ }^{-}>\mathrm{SO}_{4}{ }^{2-}>$ $\mathrm{Cl}^{-}$in equivalent units for the anions. The chemical composition of the studied groundwater can be described as calcium-bicarbonate. The calcium ions make up from $17.90 \%$ to $38.62 \%$ (30.18\% on average), and the bicarbonate ions make up from $35.30 \%$ to $48.98 \%$ (43.70\% on average) of all ions. Taken together, the calcium and bicarbonate ions make up from $61.44 \%$ to $87.60 \%$ (73.88\% on average) of all ions. The groundwater itself is of slightly alkaline nature, having $\mathrm{pH}$ of 7.3 to 8.6, and TDS of $67 \mathrm{mg} / \mathrm{l}$ to $611 \mathrm{mg} / \mathrm{l}$. One groundwater sample from the Mesta River catchment area was found to be of the low-mineralized type (TDS = $193 \mathrm{mg} / \mathrm{l}$ ) alkaline water $(\mathrm{pH}=9.8)$ in the Mesta Lowlands - the Banichan groundwater mineral source. The water can be described as sodium-bicarbonate, with sodium ions making up to $93.5 \%$ of the cations, and bicarbonate ions $-69.6 \%$ of the anions. Out of all ions, the sodium ions were found to be $48 \%$, and the bicarbonate ions $33.86 \%$. The sequence of ions is in the following order: $\mathrm{Na}^{+}>\mathrm{Ca}^{2+}>\mathrm{Mg}^{2+}>\mathrm{K}^{+}$, and $\mathrm{HCO}_{3}^{-}>\mathrm{Cl}^{-}>\mathrm{SO}_{4}^{2-}>$ $\mathrm{CO}_{3}{ }^{2-}$.
\end{abstract}

Vasileva, T., Sholev, D. 2021. Groundwater chemistry: a case study of the Mesta River Basin. Geologica Balcanica 50 (2), 35-46.

Keywords: groundwater, hydrogeochemistry, major ions, Mesta River Basin, south-western Bulgaria.

\section{INTRODUCTION}

The factors determining the geological setting for groundwater formation and its composition can be quite diverse. Their intensity can be related to any particular natural environment. The groundwater's composition, dynamics, and regime are affected to a large degree by physical-geographical factors, such as relief, climate, hydrology, and also by geological factors, such as the geological make-up and lithological composition of the rocks. The present study analyzes the natural chemical composition of groundwater samples from the Mesta River catch- ment area (taken in the month of September, 2020). Twelve natural exits of groundwater (in the form of springs) were analyzed. Some of those springs were tapped. Another aspect of the study is presenting data from the chemical analysis of a water sample taken from an abandoned well, located at the Banichan mineral water deposit. This study undertakes the task of establishing the hydrochemical facies of groundwater found in various genetic rock types.

Up until now, much research has been done regarding the chemical quality of groundwater in the Mesta River Basin. The results of several monitoring observations, as well as other hydro-chemical 
studies, focused mainly on the ecological status of groundwater, have been summarized in the River Basin Management Plan for the West Aegean region. The data can be found on the website of the Executive Environment Agency (http://www.eea. government.bg/), as well as on the web page of the Basin Directorate responsible for the West Aegean region (https://wabd.bg/content/). At present, the Basin Directorate of the West Aegean region performs monitoring activities related to the quality of groundwater at 21 monitoring points (18 controlling points and three points for operative monitoring) of the Mesta River Basin. The purpose behind this monitoring process is to evaluate the quality of groundwater found in individual administrative units - the so-called groundwater bodies (GWBs). This monitoring is of prime importance for maintaining the ecological status of groundwater in the respective GWBs, and serves as a vehicle for establishing territorial differences in groundwater sources and various anthropogenic pressures on the quality of groundwater. The aim of the present study is to collect not only samples from the same sources as the monitoring points in the West Aegean region, but also to collect the necessary data for hydro-chemical analysis of groundwater found in different types of rocks.

\section{LOCATION, GEOLOGICAL AND HYDROGEOLOGICAL SETTINGS}

The studied area is located in the south-western part of Bulgaria (Fig. 1), and has an area of 2,785 $\mathrm{km}^{2}$. It includes the Mesta River Valley (along with its tributaries), parts of the Rila and Pirin Mountains, as well as the western Rhodopes. The Razlog and Gotse Delchev Lowlands are also located in this region. According to data obtained from digital elevation models (http://srtm.csi.cgiar.org/), the topography of the catchment area can be described as consisting of low mountains with an altitude of $600-1,000 \mathrm{~m}(30.3 \%)$, and mountains of average height (1,000-1,600 m; 44.3\%). These are complemented with denudation plains, quite dissected in certain areas.

Hilly relief $(200-600 \mathrm{~m})$ covers $7.5 \%$ of the Mesta River Basin, and the high-mountain relief, with an altitude above $1,600 \mathrm{~m}$, is about $18 \%$. The average altitude of the catchment is about $1,224 \mathrm{~m}$. The annual precipitation for the period 1931-1985 for the Bansko Station was recorded as $694 \mathrm{~mm}$, and for the Gotse Delchev Station - 695 mm (Koleva and Peneva, 1990). The average annual air tempera-

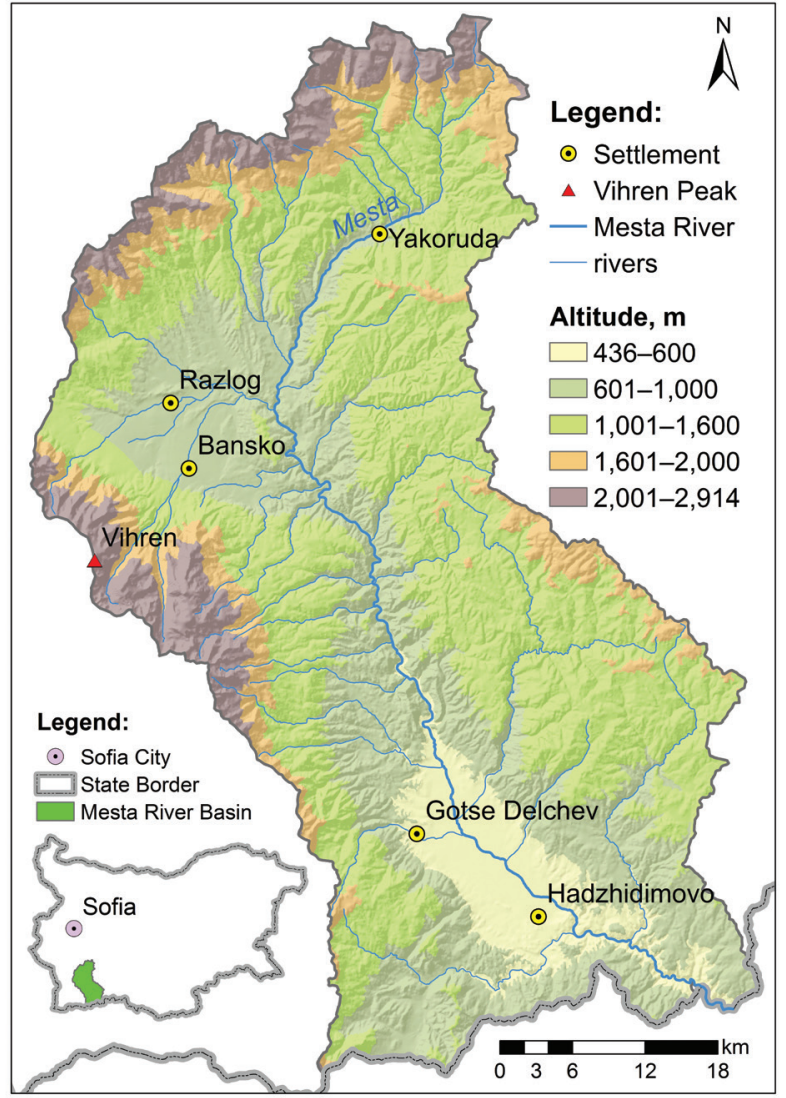

Fig. 1. Location of the Mesta River Basin.

ture for the period $1931-1970$ was $9{ }^{\circ} \mathrm{C}$ for the Bansko Station, $11.4^{\circ} \mathrm{C}$ for the Gotse Delchev Station, and $3.5^{\circ} \mathrm{C}$ for Vihren Hut (Kyuchukova, 1983). As a whole, the soil cover consists mainly of cinnamon and brown forest soils (Georgiev, 1991). According to CORINE Land Cover data (CLC, 2006 - https:// land.copernicus.eu/pan-european/corine-land-cover/ clc-2006), about a half of the catchment area (nearly $54 \%$ ) is occupied by forests. Coniferous, rather than deciduous, vegetation predominates in the studied region.

The geological background is relatively complex, with interesting relationships between magmatic, metamorphic, sedimentary, and volcanosedimentary rocks. According to the most recent geological map sheets in scale 1:50 000, both Precambrian metamorphites and Paleogene plutonic rocks have the widest prevalence (Milovanov et al., 2009a, b; Klimov et al., 2010a, b; Sarov et al., 2009a-c, 2010a-d, 2011a-c). Those rocks form the geological setting for the existing porous, cracked, and karst waters. The former are accumulated in the Pliocene and Quaternary deposits, distributed in 
the youngest graben structures (Razlog and Gotse Delchev valleys). Crack-waters form the aquifer system in the regional cracking zone in the mountainous and low-mountainous zones of Rila and Pirin, as well as the westernmost parts of Western Rhodopes. These are the most widespread types of groundwater that can be found in the studied region, and are used for drinking purposes, coming from captive springs, by many settlements.

\section{DATA ACQUISITION AND METHOD OF STUDY}

The baseline for this study is data of the chemical composition of groundwater samples taken from localities in the Mesta River Basin. The geographical coordinates of each hydrogeological element were taken into account. Each element was fixed with its latitudinal and longitudinal coordinates expressed in decimal degrees. Topographic characteristics were measured in terms of altitude expressed in meters. Temperature and hydrogen-ion activity $(\mathrm{pH})$ of groundwater were measured in the field. The groundwater samples and their chemical composition were analyzed at Aquaterratest Laboratory.
They were taken in September, 2020. Of all 13 samples, 12 were obtained from springs and one came from a borehole. As a whole, 17 physical and chemical constituents of groundwater were taken into account. The major, and commonly analyzed, elements were the following: total dissolved solids (TDS), total hardness (TH), electrical conductance (EC), permanganate oxidizability (PO), $\mathrm{F}^{-}, \mathrm{Cl}^{-}, \mathrm{NO}_{2}^{-}$, $\mathrm{NO}_{3}{ }^{-}, \mathrm{PO}_{4}{ }^{3-}, \mathrm{SO}_{4}{ }^{2-}, \mathrm{HCO}_{3}{ }^{-}, \mathrm{CO}_{3}{ }^{2-}, \mathrm{NH}_{4}^{+}, \mathrm{Ca}^{2+}, \mathrm{K}^{+}$, $\mathrm{Mg}^{2+}$, and $\mathrm{Na}^{+}$. The TDS and TH were determined by means of calculations. The temperature and $\mathrm{pH}$ were measured on location, and allowed to stabilize before the collection of samples, while their chemical parameters were determined analytically. The hydro-chemical facies of groundwater are given according to the Piper Diagram (Piper, 1944) and Chadha Diagram (Chadha, 1999), which represent a graphical procedure for interpreting the geochemical data after the analyses of the water samples.

\section{HYDROGEOCHEMISTRY}

The ground waters from the studied areas in the Mesta River Basin (Table 1) were found to have

Table 1

Results obtained for some major and commonly analyzed parameters

\begin{tabular}{|c|c|c|c|c|c|c|c|c|c|c|c|c|c|}
\hline Sample & $831-1$ & $831-2$ & $831-3$ & $831-4$ & 831-6 & $831-7$ & 831-8 & $831-9$ & $831-10$ & $831-11$ & $831-12$ & 831-13 & $831-5 * *$ \\
\hline Points* & 65 & 69 & 74 & 77 & 81 & 82 & 85 & 91 & 93 & 95 & 97 & 100 & 79 \\
\hline Level, m & 921 & 529 & 1369 & 764 & 534 & 519 & 461 & 725 & 1655 & 1671 & 1174 & 1404 & 551 \\
\hline $\mathrm{pH}$ & 7.6 & 7.6 & 7.3 & 8 & 8.6 & 7.7 & 7.9 & 8.6 & 7.7 & 8.1 & 8.5 & 7.4 & 9.8 \\
\hline $\mathrm{T},{ }^{\circ} \mathrm{C}$ & 11.3 & 11.5 & 7.0 & 12 & 20.5 & 12 & 15 & 13.2 & 8.6 & 9.6 & 9.7 & 14.1 & 14 \\
\hline TDS, mg/l & 124 & 165 & 82 & 213 & 246 & 611 & 576 & 323 & 67 & 68 & 251 & 129 & 193 \\
\hline TH, meq/l & 1.03 & 0.78 & 0.43 & 1.96 & 2.65 & 7.16 & 5.03 & 3.17 & 0.40 & 0.25 & 2.15 & 1.10 & 0.15 \\
\hline $\mathrm{EC}, \mu \mathrm{S} / \mathrm{cm}$ & 147 & 123 & 71 & 218 & 280 & 666 & 605 & 356 & 58 & 57 & 256 & 147 & 283 \\
\hline $\mathrm{PO}, \mathrm{mgO}_{2} / \mathrm{l}$ & 0.64 & 0.8 & 0.88 & 0.72 & 0.8 & 0.64 & 0.72 & 0.88 & 0.96 & 0.8 & 0.8 & 0.88 & 0.96 \\
\hline $\mathrm{F}^{-}, \mathrm{mg} / \mathrm{l}$ & $<0.1$ & $<0.1$ & $<0.1$ & 0.24 & 0.1 & 0.1 & 0.21 & $<0.1$ & $<0.1$ & $<0.1$ & $<0.1$ & $<0.1$ & 1.27 \\
\hline $\mathrm{Cl}^{-}, \mathrm{mg} / \mathrm{l}$ & 2.7 & 3.05 & 1.14 & 1.23 & 4.41 & 2.25 & 9.39 & 2.59 & 1.27 & 3.66 & 1.71 & 3.86 & 15.17 \\
\hline $\mathrm{NO}_{2}^{-}, \mathrm{mg} / \mathrm{l}$ & $<0.05$ & $<0.05$ & $<0.05$ & $<0.05$ & $<0.05$ & $<0.05$ & $<0.05$ & $<0.05$ & $<0.05$ & $<0.05$ & $<0.05$ & $<0.05$ & $<0.05$ \\
\hline $\mathrm{NO}_{3}^{-}, \mathrm{mg} / \mathrm{l}$ & 5.59 & $<0.1$ & $<0.1$ & 0.43 & $<0.1$ & $<0.1$ & $<0.1$ & 2.54 & $<0.1$ & $<0.1$ & 1.7 & 6.58 & $<0.1$ \\
\hline $\mathrm{PO}_{4}^{3-}, \mathrm{mg} / \mathrm{l}$ & $<0.1$ & $<0.1$ & $<0.1$ & $<0.1$ & $<0.1$ & $<0.1$ & $<0.1$ & $<0.1$ & $<0.1$ & $<0.1$ & $<0.1$ & $<0.1$ & $<0.1$ \\
\hline $\mathrm{SO}_{4}{ }^{2-}, \mathrm{mg} / \mathrm{l}$ & 10.54 & 12.1 & 6.86 & 9.32 & 4.63 & 7.9 & 13.03 & 20.04 & 5.57 & 3.67 & 9.55 & 14.45 & 12.63 \\
\hline $\mathrm{HCO}_{3}^{-}, \mathrm{mg} / \mathrm{l}$ & 60.52 & 57.77 & 38.51 & 123.8 & 170.6 & 442.9 & 385.1 & 203.6 & 33 & 30.26 & 148.5 & 57.77 & 96.28 \\
\hline $\mathrm{CO}_{3}{ }^{2-}, \mathrm{mg} / \mathrm{l}$ & $<5$ & $<5$ & $<5$ & $<5$ & $<5$ & $<5$ & $<5$ & $<5$ & $<5$ & $<5$ & $<5$ & $<5$ & 2.7 \\
\hline $\mathrm{NH}_{4}^{+}, \mathrm{mg} / \mathrm{l}$ & $<0.01$ & $<0.01$ & $<0.01$ & $<0.01$ & $<0.01$ & $<0.01$ & $<0.01$ & $<0.01$ & $<0.01$ & $<0.01$ & $<0.01$ & $<0.01$ & $<0.01$ \\
\hline $\mathrm{Ca}^{2+}, \mathrm{mg} / \mathrm{l}$ & 16.71 & 11.94 & 5.45 & 33.94 & 43.81 & 114.5 & 60.49 & 53.85 & 6.39 & 4.08 & 37.42 & 18.46 & 2.85 \\
\hline $\mathrm{K}^{+}, \mathrm{mg} / \mathrm{l}$ & 2.33 & 1.34 & 1.36 & 0.67 & 0.74 & 0.46 & 5.99 & 0.88 & 0.57 & 1.26 & 1.96 & 0.53 & 0.15 \\
\hline $\mathrm{Mg}^{2+}, \mathrm{mg} / \mathrm{l}$ & 2.4 & 2.29 & 1.98 & 3.18 & 5.58 & 17.52 & 24.48 & 5.89 & 1 & 0.58 & 3.46 & 2.18 & 0.11 \\
\hline $\mathrm{Na}^{+}, \mathrm{mg} / \mathrm{l}$ & 4.58 & 8.53 & 3.08 & 5.78 & 5.84 & 3.47 & 31.75 & 8.29 & 2.56 & 4.13 & 8.25 & 4.82 & 51.47 \\
\hline Si, mg/l & 6.96 & 25.08 & 8.65 & 7.15 & 3.71 & 8.09 & 16.47 & 9.19 & 6.22 & 7.33 & 14.14 & 6.96 & 12.46 \\
\hline $\mathrm{Ca}^{2+} / \mathrm{Mg}^{2+}$ ratio & 4.2 & 3.2 & 1.7 & 6.5 & 4.8 & 4.0 & 1.5 & 5.5 & 3.9 & 4.3 & 6.6 & 5.1 & 15.7 \\
\hline $\mathrm{Na}^{+} / \mathrm{Cl}^{-}$ratio & 2.6 & 4.3 & 4.2 & 7.2 & 2.0 & 2.4 & 5.2 & 4.9 & 3.1 & 1.7 & 7.4 & 1.9 & 5.2 \\
\hline
\end{tabular}

Note: *65 - Gorno Dryanovo; 69 - Gospodintsi; 74 - Popovi Livadi; 77 - Breznitsa; 81 - Sadovo; 82 - Petrelik; 85 - Hadzhidimovo; 91 - Mesta; 93 - Gotse Delchev; 95 - Treshtenik; 97 - Cherna Mesta; 100 - Avramovo; 79 - Banichan. **Sample taken from the groundwater mineral source of Banichan. 
temperatures ranging between $7.0^{\circ} \mathrm{C}$ and $20.5^{\circ} \mathrm{C}$ and tend to be slightly alkali, with low mineralization, from very soft to hard (Figs 2-4). They were found to be primarily of the calcium-bicarbonate type. The distribution of the calcium and carbonate ions is presented in Figs 5, 6. The hydrogeological units are presented in accordance with the geological map in scale 1:50,000: map sheets Velingrad (Sarov et al., 2009a), Hadzhidimovo (Sarov et al., 2010b), Gotse Delchev (Klimov et al., 2010a), Dobrinishte (Milovanov et al., 2009a), and Yakoruda (Sarov et al., 2011b). The hydrochemical types of groundwater are presented in Table 2.

According to the accepted in the Republic of Bulgaria and the EU administrative classification of groundwater bodies, eleven groundwater bodies are located in the Mesta River Basin (Fig. 7, Table 3). The monitoring points, where the operative and controlling monitoring of groundwater quality by the Executive Agency takes place, are presented in Fig. 8 and Table 4. In seven of those bodies are located the points from which samples were taken in 2020 (Fig. 7).

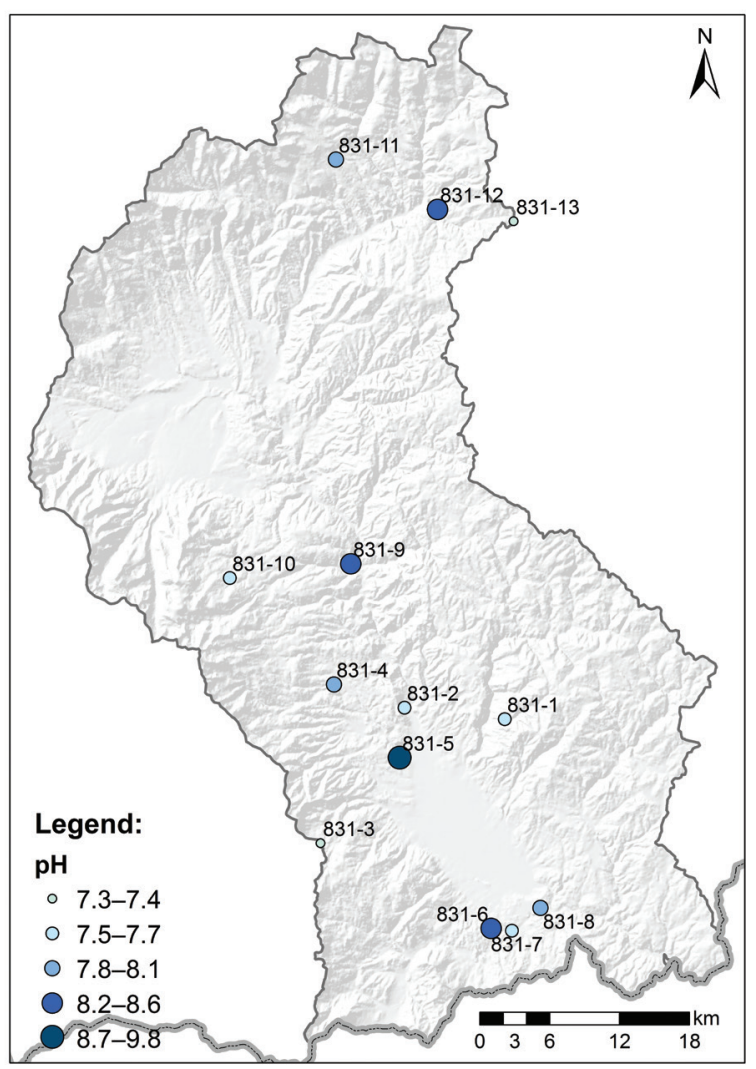

Fig. 2. Hydrogen-ion activity distribution for the Mesta River Basin.

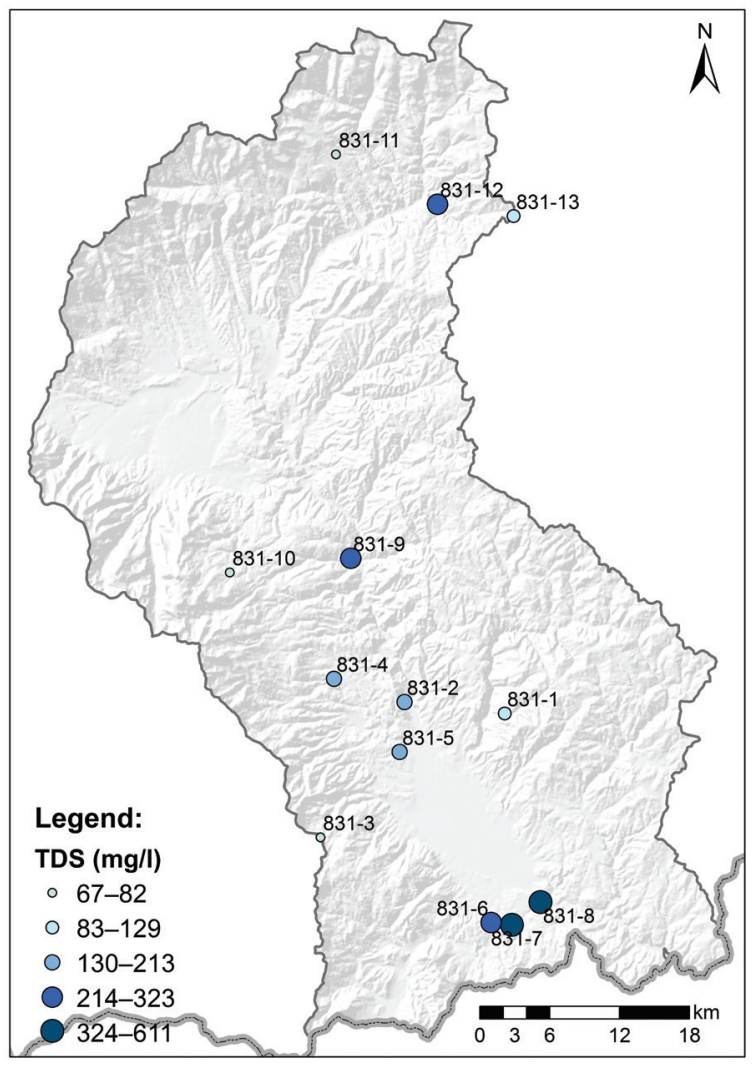

Fig. 3. Total dissolved solids distribution.

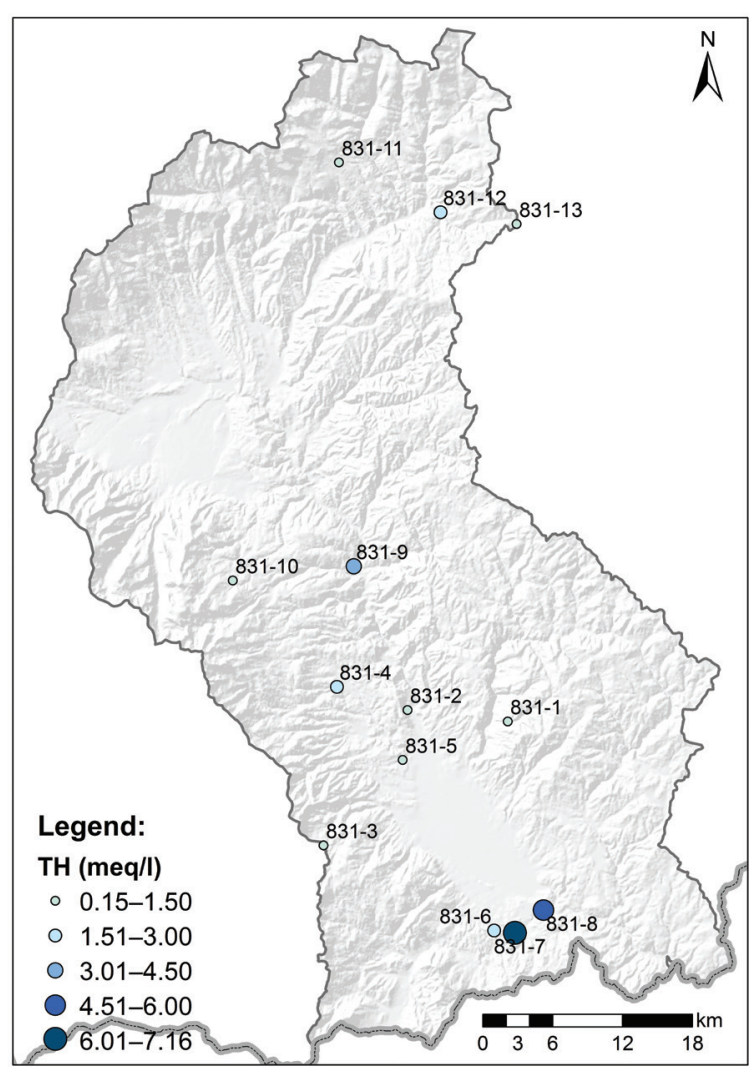

Fig. 4. Total hardness distribution. 


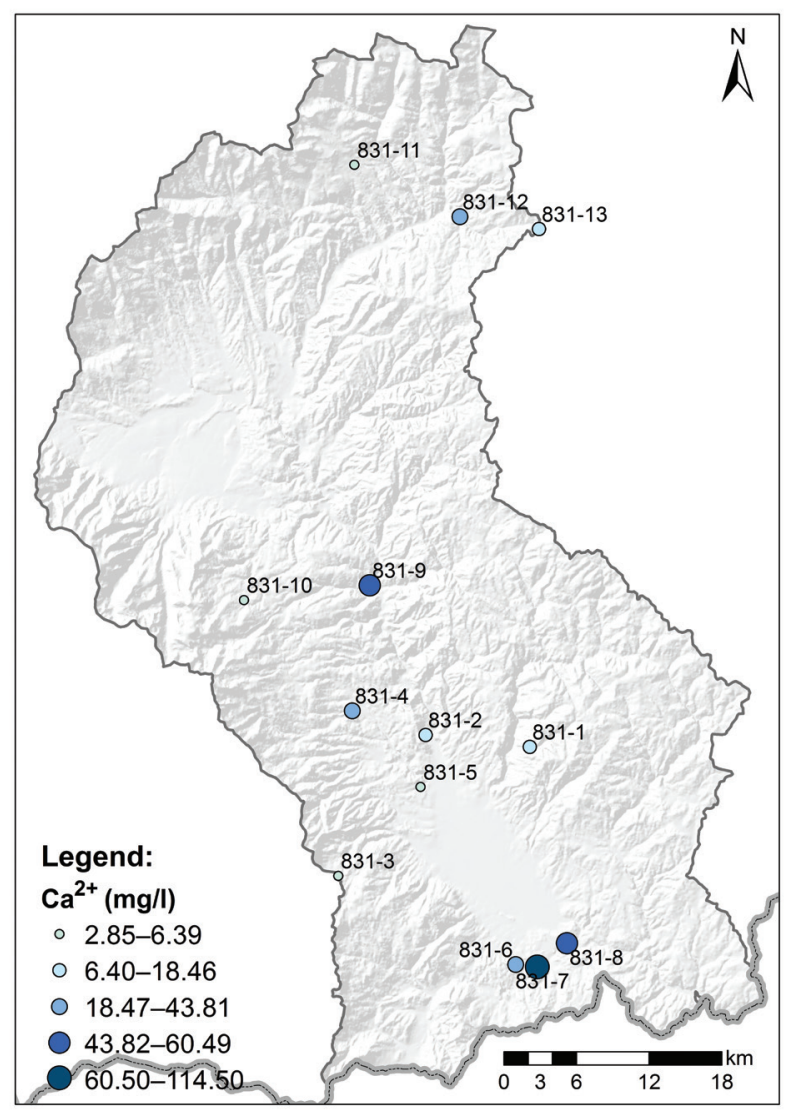

Fig. 5. Calcium distribution.

Ground waters formed in the Precambrian metamorphic rocks (metagranites of the Sarnitsa lithotectonic unit and migmatized biotite, amphibolebiotite gneiss and gneiss-schists of the Slashten lithotectonic unit) were found to be slightly mineralized in the range of $0.124 \mathrm{~g} / \mathrm{l}$ and $0.576 \mathrm{~g} / \mathrm{l}$, with $\mathrm{pH}$ between 7.6 and 7.9. The groundwater in the region was found to vary from very soft, with $\mathrm{TH}=$ $1.03 \mathrm{meq} / \mathrm{l}$ (in Gorno Dryanovo), to quite hard, with $\mathrm{TH}=5.03 \mathrm{meq} / \mathrm{l}$ (in Hadzhidimovo) (see Fig. 4). According to their chemical characteristics, they can be of calcium-bicarbonate nature (sample 831-1), as well as of calcium-magnesium-hydrocarbonate nature, with an increased sodium contents, 20.98\% of the cations or $10.28 \%$ of all ions (sample $831-8$ ). The hydrocarbonates were found to be in the range from $60.52 \mathrm{mg} / \mathrm{l}$ to $385.1 \mathrm{mg} / \mathrm{l}$ (Table 1 ). The concentration of calcium ions varies between $16.71 \mathrm{mg} / \mathrm{l}$ and $60.49 \mathrm{mg} / \mathrm{l}$, and the concentration of sodium ions varies between $4.58 \mathrm{mg} / \mathrm{l}$ and $31.75 \mathrm{mg} / \mathrm{l}$.

The ground waters found in Paleogene effusive rocks (dacites and rhyodacites) are mostly of the calcium-bicarbonate type and calcium-sodium-bi-

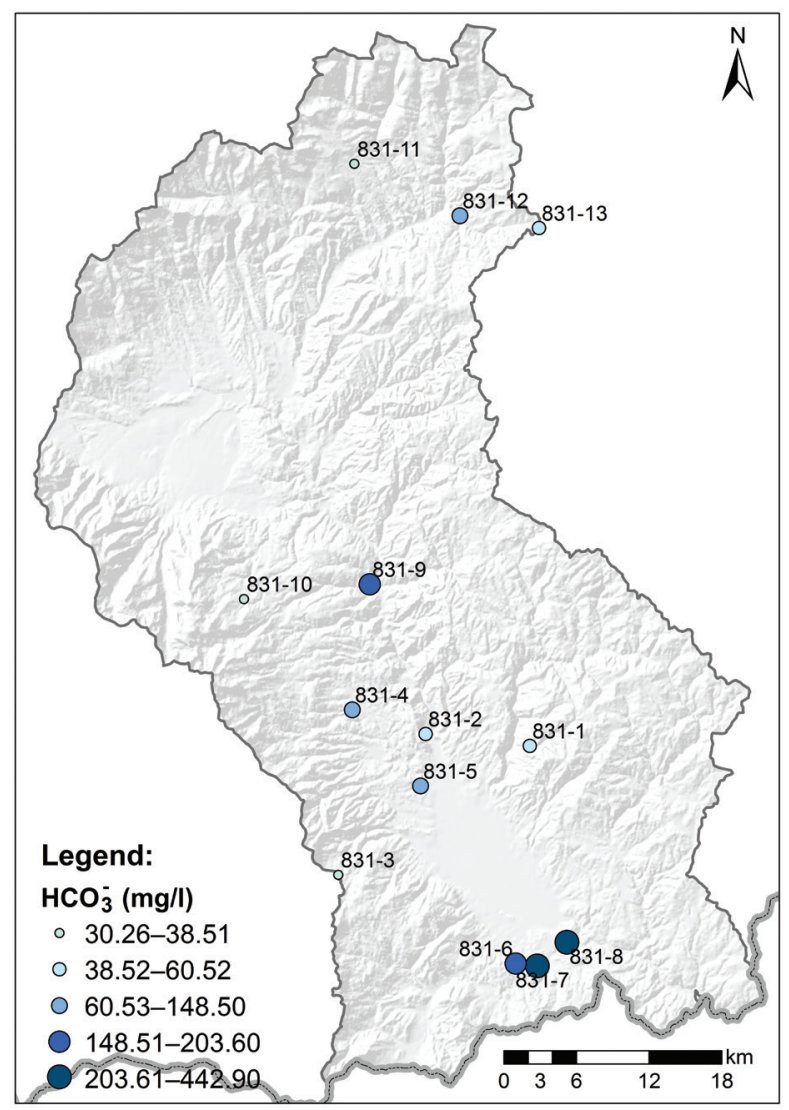

Fig. 6. Bicarbonate distribution.

carbonate type (Table 2, Fig. 9), with an increased content of sodium $(31.13 \%$ of the cations or $14.98 \%$ of all ions), and sulphate ions (19.62\% of anions, and $10.18 \%$ of all ions) (sample 831-2). The concentration of calcium ions was found to be in the range from $11.94 \mathrm{mg} / \mathrm{l}$ to $53.85 \mathrm{mg} / \mathrm{l}$, and the concentration of bicarbonate ions in the range from $57.77 \mathrm{mg} / \mathrm{l}$ to $203.6 \mathrm{mg} / \mathrm{l}$. The sulphate ions were found to be from $9.32 \mathrm{mg} / \mathrm{l}$ up to $20.04 \mathrm{mg} / \mathrm{l}$. Sample 831-5 was taken from an abandoned borehole, about $1 \mathrm{~km}$ to the west of the road from Gotse Delchev to Bansko, from the mineral water spring near Banichan Village. The collector at the Banichan deposit was found to be composed of volcanics, i.e., dacites, rhyodacites, and rhyolite tuffs, rhyolite xenotuffs, tuff sandstones, and conglomerates (Table 2). This is mineral water with prevalence of nitrogen gas, or the so-called nitrogen weakly mineralized alkaline waters (Petrov, 1964). The mineral water from the Banichan source can be described as having low content of soluble substances. The overall mineralization was found to be $193 \mathrm{mg} / \mathrm{l}$. As to the content of cations, the most prevalent are sodium cations 
Table 2

Hydro-geochemistry of the main hydrogeological units

\begin{tabular}{|c|c|c|c|c|}
\hline Sample & Age* & Hydrogeological Unit* & Unit* & $\begin{array}{l}\text { Water } \\
\text { facies }\end{array}$ \\
\hline $831-1$ & Precambrian & $\begin{array}{l}\text { Precambrian metamorphic rocks } \\
\text { with waters in weathering zone and } \\
\text { tectonic cracks }\end{array}$ & $\begin{array}{l}\text { Sarnitsa lithotectonic unit } \\
\text { (two-mica metagranites) }\end{array}$ & $\mathrm{Ca}-\mathrm{HCO}_{3}$ \\
\hline $831-8$ & & & $\begin{array}{l}\text { Slashten lithotectonic unit (migmatized } \\
\text { biotite and amphibole-biotite gneiss and } \\
\text { gneiss-schists) }\end{array}$ & $\begin{array}{l}\mathrm{Ca} / \\
\mathrm{Mg}-\mathrm{HCO}_{3}\end{array}$ \\
\hline $831-2$ & $\begin{array}{l}\text { Paleogene- } \\
\text { lower Oligocene } \\
\text { (Rupelian) }\end{array}$ & $\begin{array}{l}\text { Waters in lower Oligocene effusive } \\
\text { rocks of the Mesta River Lowland }\end{array}$ & $\begin{array}{l}\text { Dacites and rhyodacites } \\
\text { (subvolcanic and extruded bodies) }\end{array}$ & $\begin{array}{l}\mathrm{Ca} / \\
\mathrm{Na}-\mathrm{HCO}_{3}\end{array}$ \\
\hline $\begin{array}{l}831-4 \\
831-9\end{array}$ & $\begin{array}{l}\text { Paleogene-lower } \\
\text { Oligocene }\end{array}$ & $\begin{array}{l}\text { Waters in lower Oligocene effusive } \\
\text { rocks }\end{array}$ & $\begin{array}{l}\text { Rhyodacites } \\
\text { Rhyodacites }\end{array}$ & $\begin{array}{l}\mathrm{Ca}-\mathrm{HCO}_{3} \\
\mathrm{Ca}-\mathrm{HCO}_{3}\end{array}$ \\
\hline $831-5$ & $\begin{array}{l}\text { Paleogene-lower } \\
\text { Oligocene }\end{array}$ & $\begin{array}{l}\text { Mineral waters in lower Oligocene } \\
\text { effusive rocks of the Mesta Lowland }\end{array}$ & $\begin{array}{l}\text { Volcanic formation (dacites, rhyodacites } \\
\text { and rhyolite tuffs, rhyolite xenotuffs, tuff } \\
\text { sandstones and conglomerates) }\end{array}$ & $\mathrm{Na}-\mathrm{HCO}_{3}$ \\
\hline $831-3$ & $\begin{array}{l}\text { Paleogene-lower } \\
\text { Oligocene }\end{array}$ & $\begin{array}{l}\text { Waters in lower Oligocene intrusive } \\
\text { rocks }\end{array}$ & $\begin{array}{l}\text { Teshovo pluton (medium-grained amphi- } \\
\text { bole-biotite granodiorites) }\end{array}$ & $\begin{array}{l}\mathrm{Ca} / \\
\mathrm{Mg}-\mathrm{HCO}_{3}\end{array}$ \\
\hline $831-10$ & Paleogene & Waters in Paleogene intrusive rocks & $\begin{array}{l}\text { Central Pirin pluton (coarse-porphyric } \\
\text { biotite granites to granodiorites, Bezbog } \\
\text { type granitoids) }\end{array}$ & $\mathrm{Ca}-\mathrm{HCO}_{3}$ \\
\hline $\begin{array}{l}831-12 \\
831-13\end{array}$ & $\begin{array}{l}\text { Paleogene } \\
\text { Palaeogene } \\
\text { (Lutetian?) }\end{array}$ & $\begin{array}{l}\text { Paleogene intrusive rocks with wa- } \\
\text { ters in weathering zone and tectonic } \\
\text { cracks }\end{array}$ & $\begin{array}{l}\text { Rila-West Rhodope batholith (granites - } \\
\text { medium to fine-grained biotite granites) }\end{array}$ & $\begin{array}{l}\mathrm{Ca}-\mathrm{HCO}_{3} \\
\mathrm{Ca}-\mathrm{HCO}_{3}\end{array}$ \\
\hline 831-11 & Paleogene & $\begin{array}{l}\text { Paleogene intrusive rocks with wa- } \\
\text { ters in weathering zone and tectonic } \\
\text { cracks }\end{array}$ & $\begin{array}{l}\text { Rila-West Rhodope batholith (granodior- } \\
\text { ites - porphyric granodiorites) }\end{array}$ & $\begin{array}{l}\mathrm{Ca} / \\
\mathrm{Na}-\mathrm{HCO}_{3}\end{array}$ \\
\hline $\begin{array}{l}831-6 \\
831-7\end{array}$ & $\begin{array}{l}\text { upper } \\
\text { Miocene-Pliocene }\end{array}$ & $\begin{array}{l}\text { upper Miocene-Pliocene sedimen- } \\
\text { tary water complex }\end{array}$ & $\begin{array}{l}\text { Conglomerate and sandstone formation } \\
\text { (breccia-conglomerates, conglomerates } \\
\text { and sandstones) }\end{array}$ & $\begin{array}{l}\mathrm{Ca}-\mathrm{HCO}_{3} \\
\mathrm{Ca}-\mathrm{HCO}_{3}\end{array}$ \\
\hline
\end{tabular}

Note: *According to the geological map sheets in scale 1:50,000 (Sarov et al., 2009c, 2010a, 2010b, 2011b; Klimov et al., 2010b).

(see Fig. 9), and the most prevalent anions are bicarbonate ions. According to its type, the mineral water tends to be of bicarbonate-sodium nature, with bicarbonate ions (69.57\%); the contents of sulphate and other anions exceeds $25 \%\left(\mathrm{SO}_{4}{ }^{2-}-11.60 \%\right.$, and $\mathrm{Cl}^{-}-18.83 \%$ ), whereas sodium prevails over other cations at $93.51 \%$. The water is characterized by high $\mathrm{pH}=9.8$, low mineralization, and temperature of $14{ }^{\circ} \mathrm{C}$, silicon concentration of $12.46 \mathrm{mg} / \mathrm{l}$, and fluoride content of $1.27 \mathrm{mg} / \mathrm{l}$ (Table 1).

The Paleogene plutonic rocks (granites and granodiorites) (Table 2) host groundwater of the calcium-bicarbonate type with a higher number of sodium ions, $21.08 \%$ of the cations or $9.12 \%$ of the sum total of all ions (for sample 831-10); calciumsodium-bicarbonate type with sodium ions amounting to $38.72 \%$ of all cations, or $15.76 \%$ of all ions (for sample 831-11), and with a higher sulphate content (20.58\% of anions and $10.79 \%$ of all ions) (sample 831-13); calcium-bicarbonate type (sample 831-3) with a higher number of magnesium ions, $27.05 \%$ of all cations and $11.60 \%$ concentration of all ions, and sodium ions $(22.14 \%$ of all cations, or $9.49 \%$ of all ions). The concentration of bicarbonate ions varies in the range from $30.26 \mathrm{mg} / \mathrm{l}$ up to $148.5 \mathrm{mg} / \mathrm{l}$, and the concentration of calcium ions varies from $4.08 \mathrm{mg} / \mathrm{l}$ to $37.42 \mathrm{mg} / \mathrm{l}$.

Ground waters of the upper Miocene-Pliocene sedimentary complex (breccia-conglomerates, conglomerates, sandstones) can be described as belonging to the calcium-bicarbonate type (Table 2), varying from soft (sample 831-6) to hard (sample 831-7), with an increased content of magnesium ions, $19.74 \%$ of all cations and $9.77 \%$ of the concentration of all ions (sample 831-7). The concentration of bicarbonate ions varies from $170.6 \mathrm{mg} / \mathrm{l}$ to $442.9 \mathrm{mg} / \mathrm{l}$, and the concentration of calcium ions varies from $43.81 \mathrm{mg} / \mathrm{l}$ to $114.5 \mathrm{mg} / \mathrm{l}$. The magnesium ions 


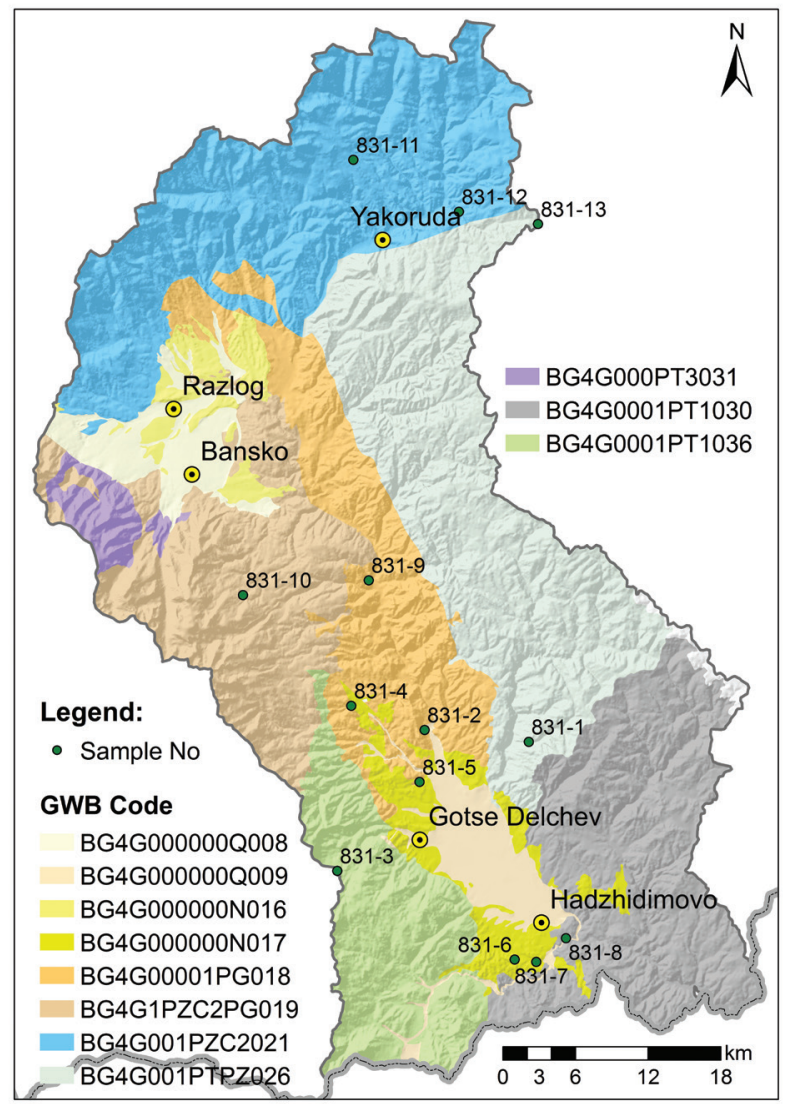

Fig. 7. Groundwater bodies in the Mesta River Basin (according to the River Basin Management Plans of the West Aegean Region).

were found to be in the range between $5.58 \mathrm{mg} / \mathrm{l}$ and $17.52 \mathrm{mg} / \mathrm{l}$ (for sample 831-7).

From the hydrogeochemical interpretation of water analyses, carried out on the studied samples from the Mesta River Basin, and the Piper Diagram (Piper, 1944), which shows their major ion chemistry, it follows that in the studied samples: 1) alkaline earth metals $\left(\mathrm{Ca}^{2+}+\mathrm{Mg}^{2+}\right)$ exceed alkali metals $\left(\mathrm{Na}^{+}+\mathrm{K}^{+}\right)$; 2) weak acids $\left(\mathrm{CO}_{3}{ }^{2-}+\mathrm{HCO}_{3}{ }^{-}\right)$ exceed strong acids $\left(\mathrm{SO}_{4}{ }^{2-}+\mathrm{Cl}^{-}\right)$; and 3 ) carbonate hardness exceeds $50 \%$, i.e., prevalent in the groundwater samples were alkaline earths and weak acids (Fig. 9). This fact has also been confirmed by the Chadha Diagram (Chadha, 1999) (Fig. 10). For waters coming from the groundwater mineral source of Banichan, alkalis exceed the alkaline earths, and weak acids exceed the strong acids, while the carbonate alkali exceed 50\%, meaning that groundwater is inordinately soft in proportion to its content of dissolved solids. The Chadha Diagram (Chadha, 1999) contributes to the understanding of the basic

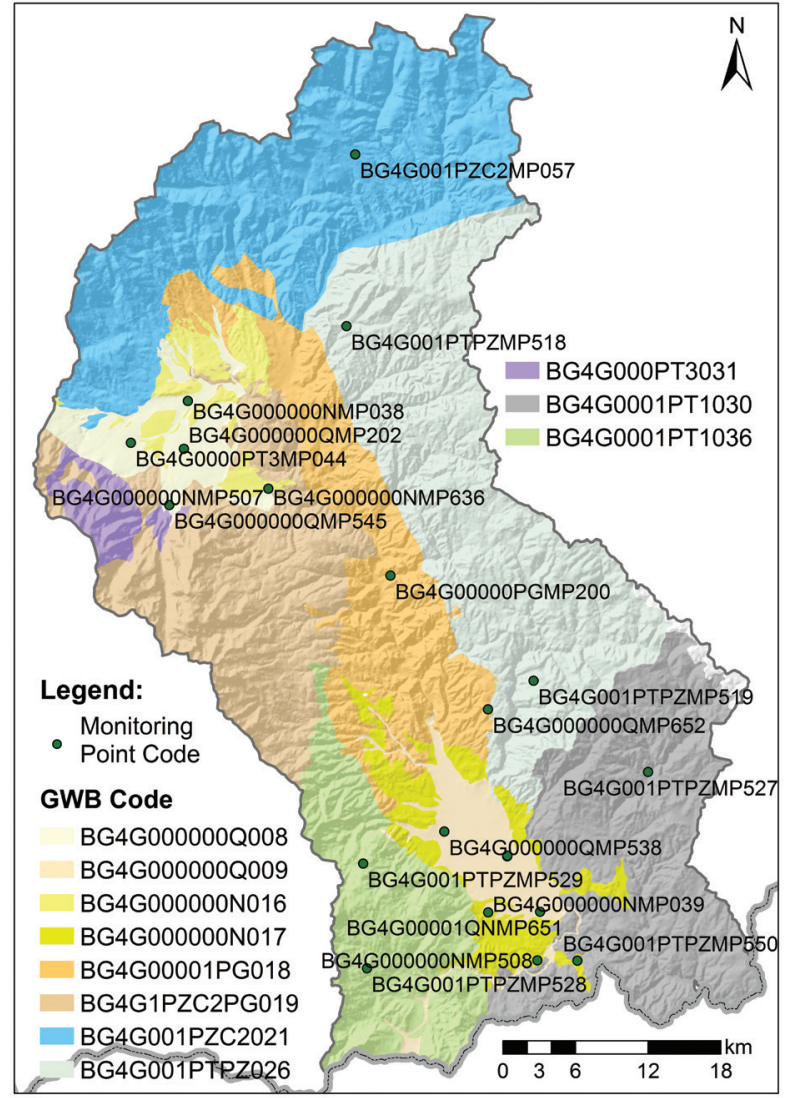

Fig. 8. Groundwater monitoring points and groundwater bodies in the Mesta River Basin (according to the River Basin Management Plans of the West Aegean region).

geochemical processes influencing the quality of groundwater. Twelve of the samples can be defined as $\mathrm{Ca}-\mathrm{HCO}_{3}$ water recharge types, and one of the samples is dominated by an ion exchange (Fig. 10), proving that the base ion exchange is the domineering factor in the formation of groundwater, and leads to an exchange of $\mathrm{Ca}^{2+}$ and $\mathrm{Mg}^{2+}$ ions from groundwater with $\mathrm{Na}^{+}$and $\mathrm{K}^{+}$ions from the host rock.

For all the studied samples, it can be concluded that the water composition is similar for plutonic, metamorphic, sandstones and volcanic rocks, the only exception being sample 831-5 (Table 5).

The obtained result for the ratio $\mathrm{Na}^{+} / \mathrm{Cl}^{-}>1$ (Rajesh et al., 2011) testifies of an increased presence of sodium in the groundwater, most likely as a result of silicate weathering, or of ion exchange between sodium from rocks and calcium from groundwater. The ratio $\mathrm{Ca}^{2+} / \mathrm{Mg}^{2+}>1$ (Li et al., 2018) is indicative of the presence of Ca ions in the groundwater as a result of calcite dissolution (samples 831-3 and $831-8)$. The ratio $\mathrm{Ca}^{2+} / \mathrm{Mg}^{2+}>2$ is indicative of 
Table 3

Main hydrogeological units and groundwater bodies

\begin{tabular}{|c|c|c|c|c|c|c|}
\hline Sample & Point* & Age** & $\begin{array}{l}\text { Hydrogeological } \\
\text { Unit** }\end{array}$ & Unit** & GWB Code*** & GWB Name*** \\
\hline 831-1 & 65 & Precambrian & $\begin{array}{l}\text { Precambrian meta- } \\
\text { morphic rocks with } \\
\text { waters in weathering } \\
\text { zone and tectonic } \\
\text { cracks }\end{array}$ & $\begin{array}{l}\text { Sarnitsa lithotec- } \\
\text { tonic unit (two-mica } \\
\text { metagranites) }\end{array}$ & BG4G001PTPZ026 & $\begin{array}{l}\text { Fissured groundwater } \\
\text { in "South-Bulgarian } \\
\text { granites", "Western } \\
\text { Rhodope metamor- } \\
\text { phic rocks”, Barutin- } \\
\text { Buynovo pluton }\end{array}$ \\
\hline 831-8 & 85 & & & $\begin{array}{l}\text { Slashten lithotectonic } \\
\text { unit (migmatized bio- } \\
\text { tite and amphibole- } \\
\text { biotite gneiss and } \\
\text { gneiss-schists) }\end{array}$ & BG4G0001PT1030 & $\begin{array}{l}\text { Fissured-karst } \\
\text { groundwater in } \\
\text { Satovcha karst basin, } \\
\text { Dolno Dryanovo } \\
\text { pluton }\end{array}$ \\
\hline $831-2$ & 69 & $\begin{array}{l}\text { Paleogene- } \\
\text { lower } \\
\text { Oligocene } \\
\text { (Rupelian) }\end{array}$ & $\begin{array}{l}\text { Waters in lower } \\
\text { Oligocene effusive } \\
\text { rocks of the Mesta } \\
\text { River Lowland }\end{array}$ & $\begin{array}{l}\text { Dacites and rhyodac- } \\
\text { ites (subvolcanic and } \\
\text { extruded bodies) }\end{array}$ & BG4G00001PG018 & $\begin{array}{l}\text { Porous-fissured } \\
\text { groundwater in } \\
\text { the Gotse Delchev } \\
\text { Paleogene aquifer }\end{array}$ \\
\hline 831-4 & 77 & $\begin{array}{l}\text { Paleogene- } \\
\text { lower } \\
\text { Oligocene }\end{array}$ & $\begin{array}{l}\text { Waters in lower } \\
\text { Oligocene effusive } \\
\text { rocks }\end{array}$ & Rhyodacites & BG4G00001PG018 & $\begin{array}{l}\text { Porous-fissured } \\
\text { groundwater in } \\
\text { the Gotse Delchev } \\
\text { Paleogene aquifer }\end{array}$ \\
\hline $831-9$ & 91 & & & Rhyodacites & BG4G00001PG018 & $\begin{array}{l}\text { Porous-fissured } \\
\text { groundwater in } \\
\text { the Gotse Delchev } \\
\text { Paleogene aquifer }\end{array}$ \\
\hline $831-5$ & 79 & $\begin{array}{l}\text { Paleogene- } \\
\text { lower } \\
\text { Oligocene }\end{array}$ & $\begin{array}{l}\text { Mineral waters in } \\
\text { lower Oligocene } \\
\text { effusive rocks of the } \\
\text { Mesta Lowland }\end{array}$ & $\begin{array}{l}\text { Volcanic formation } \\
\text { (dacites, rhyodacites } \\
\text { and rhyolite tuffs, } \\
\text { rhyolite xenotuffs, } \\
\text { tuff sandstones and } \\
\text { conglomerates) }\end{array}$ & - & - \\
\hline $831-3$ & 74 & $\begin{array}{l}\text { Paleogene- } \\
\text { lower } \\
\text { Oligocene }\end{array}$ & $\begin{array}{l}\text { Waters in lower } \\
\text { Oligocene intrusive } \\
\text { rocks }\end{array}$ & $\begin{array}{l}\text { Teshovo pluton } \\
\text { (medium-grained } \\
\text { amphibole-biotite } \\
\text { granodiorites) }\end{array}$ & BG4G0001PT1036 & $\begin{array}{l}\text { Fissured-karst } \\
\text { groundwater in the } \\
\text { Gotse Delchev karst } \\
\text { basin and Teshovo } \\
\text { pluton }\end{array}$ \\
\hline 831-10 & 93 & Paleogene & $\begin{array}{l}\text { Waters in Paleogene } \\
\text { intrusive rocks }\end{array}$ & $\begin{array}{l}\text { Central Pirin pluton } \\
\text { (coarse-porphyric } \\
\text { biotite granites to } \\
\text { granodiorites, Bezbog } \\
\text { type of granitoids) }\end{array}$ & BG4G1PZC2PG019 & $\begin{array}{l}\text { Fissured groundwa- } \\
\text { ter in Pirin block }\end{array}$ \\
\hline 831-12 & 97 & Paleogene & $\begin{array}{l}\text { Paleogene intrusive } \\
\text { rocks with waters in } \\
\text { weathering zone and } \\
\text { tectonic cracks }\end{array}$ & $\begin{array}{l}\text { Rila-West Rhodope } \\
\text { batholith (gran- } \\
\text { ites - medium to } \\
\text { fine-grained biotite } \\
\text { granites) }\end{array}$ & BG4G001PZC2021 & $\begin{array}{l}\text { Fissured groundwa- } \\
\text { ter in "Rila-Rhodope } \\
\text { metamorphic rocks”, } \\
\text { "South-Bulgarian } \\
\text { granites”, Kalina } \\
\text { pluton }\end{array}$ \\
\hline 831-13 & 100 & $\begin{array}{l}\text { Paleogene } \\
\text { (Lutetian?) }\end{array}$ & & & BG4G001PTPZ026 & $\begin{array}{l}\text { Fissured groundwater } \\
\text { in "South-Bulgarian } \\
\text { granites", "Western } \\
\text { Rhodope metamor- } \\
\text { phic rocks", Barutin- } \\
\text { Buynovo pluton }\end{array}$ \\
\hline 831-11 & 95 & Paleogene & $\begin{array}{l}\text { Paleogene intrusive } \\
\text { rocks with waters in } \\
\text { weathering zone and } \\
\text { tectonic cracks }\end{array}$ & $\begin{array}{l}\text { Rila-West Rhodope } \\
\text { batholith (granodi- } \\
\text { orites - porphyric } \\
\text { granodiorites) }\end{array}$ & BG4G001PZC2021 & $\begin{array}{l}\text { Fissured groundwa- } \\
\text { ter in Rila-Rodope } \\
\text { metamorphic rocks, } \\
\text { South-Bulgarian } \\
\text { granites, Kalina } \\
\text { pluton }\end{array}$ \\
\hline
\end{tabular}


Table 3 (continued)

\begin{tabular}{|c|c|c|c|c|c|c|}
\hline $831-6$ & 81 & $\begin{array}{l}\text { Upper } \\
\text { Miocene- } \\
\text { Pliocene }\end{array}$ & $\begin{array}{l}\text { upper Miocene-- } \\
\text { Pliocene sedimentary } \\
\text { water complex }\end{array}$ & $\begin{array}{l}\text { Conglomerate and } \\
\text { sandstone formation } \\
\text { (breccia-conglomer- }\end{array}$ & BG4G000000N017 & $\begin{array}{l}\text { Porous groundwater } \\
\text { in Neogene-Gotse } \\
\text { Delchev Basin }\end{array}$ \\
\hline $831-7$ & 82 & & & $\begin{array}{l}\text { ates, conglomerates } \\
\text { and sandstones) }\end{array}$ & BG4G000000N017 & $\begin{array}{l}\text { Porous groundwater } \\
\text { in Neogene-Gotse } \\
\text { Delchev Basin }\end{array}$ \\
\hline
\end{tabular}

Note: *65-Gorno Dryanovo; 69 - Gospodintsi; 74 - Popovi Livadi; 77 - Breznitsa; 81 - Sadovo; 82 - Petrelik; 85 - Hadzhidimovo; 91 - Mesta; 93 - Gotse Delchev; 95 - Treshtenik; 97 - Cherna Mesta; 100 - Avramovo; 79 - Banichan; **According to the geological map sheets in scale 1:50,000 (Sarov et al., 2009c, 2010a, 2010b, 2011b; Klimov et al., 2010b); ***According to the geological map sheets in scale 1:100,000 (Dimitrova and Katzkov, 1990; Kozhoukharov et al., 1990; Marinova and Katzkov, 1990; Marinova and Zagorchev, 1990; Kozhoukharov and Marinova, 1991; Marinova, 1991); GWB - Groundwater Body according to the River Basin Management Plans, West Aegean Region, Mesta River Basin (https://wabd.bg/content/).

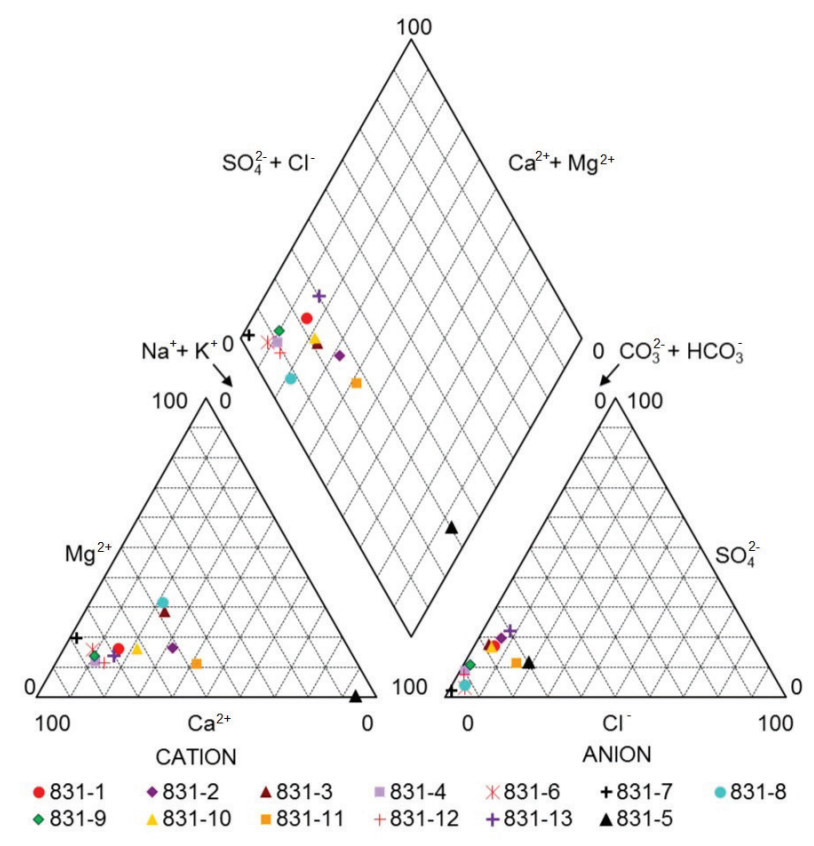

Fig. 9. Water-analysis diagram showing the major ion chemistry according to Piper (1944).

silicate mineral dissolution. Silicate weathering is one of the major processes that release $\mathrm{Na}^{+}$and $\mathrm{K}^{+}$ in groundwater from plutonic rocks. With the exception of samples 831-1 and 831-13, all samples showed $\mathrm{HCO}_{3}^{-}>\left(\mathrm{Ca}^{2+}+\mathrm{Mg}^{2+}\right)$ between the equivalent ion concentrations (Pentchev et al., 1990), proving that waters can be formed by means of in-part dissolution (leaching) of silicate rocks, and contain considerable quantities of sodium and calcium. The only exception is sample 831-5, where the ion sequence in equivalent concentrations $\mathrm{HCO}_{3}{ }^{-}>$ $\left(\mathrm{Ca}^{2+}+\mathrm{Mg}^{2+}\right)$ shows water formation based on ion

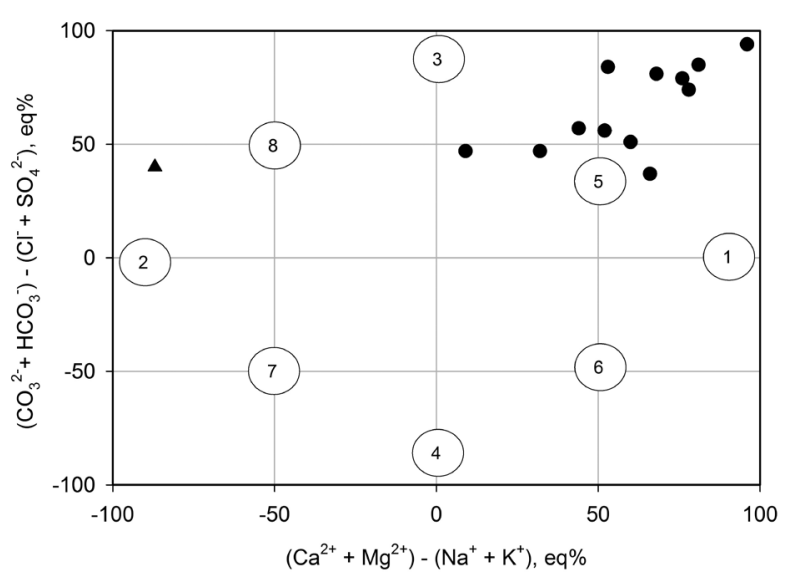

Fig. 10. Diagram showing the major ion chemistry according to Chadha (1999).

exchange of calcium from the liquid phase of sodium from the host rock.

\section{CONCLUSION}

The groundwater of the Mesta River Basin can be described as slightly alkali, with $\mathrm{pH}$ values ranging between 7.3 and 8.6, and temperatures between $7.0^{\circ} \mathrm{C}$ and $20.5^{\circ} \mathrm{C}$. The cation content was established to be in the following order: $\mathrm{Ca}^{2+}>\mathrm{Na}^{+}>\mathrm{Mg}^{2+}>\mathrm{K}^{+}$, and $\mathrm{Ca}^{2+}>\mathrm{Mg}^{2+}>\mathrm{Na}^{+}>\mathrm{K}^{+}$; for the anions, the order is $\mathrm{HCO}_{3}{ }^{-}>\mathrm{SO}_{4}{ }^{2-}>\mathrm{Cl}^{-}$. The groundwater mineralization was established as ranging between $67 \mathrm{mg} / \mathrm{l}$ and $611 \mathrm{mg} / \mathrm{l}$. The groundwater in the studied area can be described as being from very soft to hard, of bicarbonate nature, such as: 1) calcium-bicarbonate; and 2) sodium-bicarbonate (volcanic formations with mineral waters - dacites, rhyodacites and rhyolite 
Table 4

Groundwater monitoring points (for controlling and operative monitoring) and groundwater bodies in the Mesta River Basin

\begin{tabular}{|c|c|c|c|c|c|}
\hline $\mathrm{X}, \mathrm{DD}$ & Y, DD & Location & MP Code & GWB Code* & GWB Name* \\
\hline 23.48206 & 41.88844 & Razlog & BG4G000000NMP038 & BG4G000000N016 & $\begin{array}{l}\text { Porous groundwater in the } \\
\text { Neogene (Razlog) }\end{array}$ \\
\hline 23.5656 & 41.82564 & Dobrinishte & BG4G000000NMP507 & BG4G000000N016 & $\begin{array}{l}\text { Porous groundwater in the } \\
\text { Neogene (Razlog) }\end{array}$ \\
\hline 23.56561 & 41.82564 & Dobrinishte & BG4G000000NMP636 & BG4G000000N016 & $\begin{array}{l}\text { Porous groundwater in the } \\
\text { Neogene (Razlog) }\end{array}$ \\
\hline 23.79959 & 41.51717 & Koprivlen & BG4G000000NMP039 & BG4G000000N017 & $\begin{array}{l}\text { Porous groundwater in the } \\
\text { Neogene (Gotse Delchev) }\end{array}$ \\
\hline 23.85008 & 41.48287 & Petrelik & BG4G000000NMP508 & BG4G000000N017 & $\begin{array}{l}\text { Porous groundwater in the } \\
\text { Neogene (Gotse Delchev) }\end{array}$ \\
\hline 23.48 & 41.85277 & Bansko & BG4G000000QMP202 & BG4G000000Q008 & $\begin{array}{l}\text { Porous groundwater in the } \\
\text { Quaternary (Razlog) }\end{array}$ \\
\hline 23.46778 & 41.81048 & Bansko & BG4G000000QMP545 & BG4G000000Q008 & $\begin{array}{l}\text { Porous groundwater in the } \\
\text { Quaternary (Razlog) }\end{array}$ \\
\hline 23.81639 & 41.55939 & Koprivlen & BG4G000000QMP077** & BG4G000000Q009 & $\begin{array}{l}\text { Porous groundwater in the } \\
\text { Quaternary (Gotse Delchev) }\end{array}$ \\
\hline 23.81664 & 41.55983 & Dabnitsa & BG4G000000QMP201** & BG4G000000Q009 & $\begin{array}{l}\text { Porous groundwater in the } \\
\text { Quaternary (Gotse Delchev) }\end{array}$ \\
\hline 23.75322 & 41.57606 & Gotse Delchev & BG4G000000QMP538** & BG4G000000Q009 & $\begin{array}{l}\text { Porous groundwater in the } \\
\text { Quaternary (Gotse Delchev) }\end{array}$ \\
\hline 23.851 & 41.519 & Hadzhidimovo & BG4G00001QNMP651 & BG4G000000Q009 & $\begin{array}{l}\text { Porous groundwater in the } \\
\text { Quaternary (Gotse Delchev) }\end{array}$ \\
\hline 23.69027 & 41.76472 & Filipovo & BG4G00000PGMP200 & BG4G00000PG018 & $\begin{array}{l}\text { Porous-fissured groundwa- } \\
\text { ter in the Gotse Delchev } \\
\text { Paleogene aquifer }\end{array}$ \\
\hline 23.792 & 41.668 & Skrebatno & BG4G000000QMP652 & BG4G00000PG018 & $\begin{array}{l}\text { Porous-Fissured ground- } \\
\text { water in the Gotse Delchev } \\
\text { Paleogene aquifer }\end{array}$ \\
\hline 23.88965 & 41.4837 & Petrelik & BG4G001PTPZMP550 & BG4G0000PT1030 & $\begin{array}{l}\text { Fissured-karst groundwater in } \\
\text { Satovcha karst basin, Dolno } \\
\text { Dryanovo pluton }\end{array}$ \\
\hline 23.95287 & 41.62579 & Pletena & BG4G001PTPZMP527 & BG4G0000PT1030 & $\begin{array}{l}\text { Fissured-karst groundwater in } \\
\text { Satovcha karst basin, Dolno } \\
\text { Dryanovo pluton }\end{array}$ \\
\hline 23.68193 & 41.47225 & Teshovo & BG4G001PTPZMP528 & BG4G0000PT1036 & $\begin{array}{l}\text { Fissured-karst groundwater } \\
\text { in Gotse Delchev karst basin, } \\
\text { Teshovo pluton }\end{array}$ \\
\hline 23.67416 & 41.54984 & Delchevo & BG4G001PTPZMP529 & BG4G0000PT1036 & $\begin{array}{l}\text { Fissured-karst groundwater } \\
\text { in Gotse Delchev karst basin, } \\
\text { Teshovo pluton }\end{array}$ \\
\hline 23.42706 & 41.85561 & Razlog & BG4G0000РT3МP044 & BG4G0000PT3031 & $\begin{array}{l}\text { Karst groundwater in Razlog } \\
\text { karst basin }\end{array}$ \\
\hline 23.63686 & 41.9487 & Lutovo & BG4G001PTPZMP518 & BG4G000PTPZ026 & $\begin{array}{l}\text { Fissured groundwater in } \\
\text { "South-Bulgarian granites", } \\
\text { "Western Rhodope metamor- } \\
\text { phic rocks”, Barutin-Buynovo } \\
\text { pluton }\end{array}$ \\
\hline 23.83617 & 41.69053 & Kovachevitsa & BG4G001PTPZMP519 & BG4G000PTPZ026 & (ibid., 23.63686) \\
\hline 23.63889 & 42.07658 & Yakoruda & BG4G001PZC2MP057 & BG4G000PZC2021 & $\begin{array}{l}\text { Fissured groundwater in "Rila- } \\
\text { Rhodope metamorphic rocks", } \\
\text { "South-Bulgarian granites", } \\
\text { Kalina pluton }\end{array}$ \\
\hline
\end{tabular}

Note: MP - Monitoring Point; GWB - Groundwater Body according to River Basin Management Plans, West Aegean Region; *According to the geological map sheets in scale 1:100,000 (Dimitrova and Katzkov, 1990; Kozhoukharov et al., 1990; Marinova and Katzkov, 1990; Marinova and Zagorchev, 1990; Kozhoukharov and Marinova, 1991; Marinova, 1991); **Monitoring Point for operative monitoring 
Table 5

Cation and anion order in waters draining different genesis rocks in the Mesta River Basin (shown as percentage of cation and anion sum total)

\begin{tabular}{lccccccc}
\hline & $\mathrm{Ca}^{2+}$ & $\mathrm{Mg}^{2+}$ & $\mathrm{Na}^{+}$ & $\mathrm{K}^{+}$ & $\mathrm{HCO}_{3}^{-}$ & $\mathrm{SO}_{4}^{2-}$ & $\mathrm{Cl}^{-}$ \\
\hline Plutonic (granites, granodiorites) & 58.41 & 15.55 & 22.34 & 3.69 & 76.88 & 14.74 & 6.72 \\
Volcanic (dacites and rhyodacites) & 67.28 & 13.78 & 17.51 & 1.43 & 83.19 & 12.99 & 3.37 \\
Sedimentary (conglomerates, sandstones) & 76.47 & 17.75 & 5.37 & 0.4 & 94.82 & 2.7 & 2.48 \\
Metamorphic (metagranites, gneiss and gneiss-schists) & 55.3 & 23.04 & 18.19 & 3.47 & 82.09 & 9.95 & 4.69 \\
Volcanic formation* & 5.95 & 0.38 & 93.51 & 0.16 & $70.15 * *$ & 11.38 & 18.47 \\
\hline
\end{tabular}

Note: *Volcanic formation with mineral waters (Sample 831-5) - dacites, rhyodacites and rhyolite tuffs, rhyolite xenotuffs, tuff sandstones and conglomerates. $* *\left(\mathrm{HCO}_{3}{ }^{-}+\mathrm{CO}_{3}{ }^{2-}\right)$.

tuffs, rhyolite xenotuffs, tuff sandstones, and conglomerates), where $\mathrm{HCO}_{3}^{-}$are the dominant anions, with concentrations of silicon from $3.71 \mathrm{mg} / \mathrm{l}$ to $25.08 \mathrm{mg} / \mathrm{l}$. The EC is $57-666 \mathrm{mS} / \mathrm{cm}$. There could not be found any distinguishable groundwater chemistry applicable to any stratigraphic unit. The only exception is sodium-bicarbonate mineral groundwater from volcanic rocks (dacites, rhyodacites and rhyolite tuffs, rhyolite xenotuffs, tuff sandstones and conglomerates). The groundwater mineralization can be described as low, and it does not depend on the type of rocks, meaning the waters are young and of the infiltrating type, actively recharged by precipitation with chloride concentrations of up to $9.39 \mathrm{mg} / \mathrm{l}$.

As far as the Banichan mineral water is concerned, it was found to be of alkali nature, with low mineralization. The cation content is predominantly sodium (93.51\%), and the remaining cation content was $6.49 \%$. The bicarbonates, along with carbonates, form $70.15 \%$ of the content of sulphate and other anions under $25 \%\left(\mathrm{SO}_{4}{ }^{2-}-11.38 \%\right.$, and $\mathrm{Cl}^{-}$
- 18.47\%). The content of cations and anions was found to be in the sequence of $\mathrm{Na}^{+}>\mathrm{Ca}^{2+}>\mathrm{Mg}^{2+}>$ $\mathrm{K}^{+}$, and $\mathrm{HCO}_{3}^{-}>\mathrm{Cl}^{-}>\mathrm{SO}_{4}{ }^{2-}>\mathrm{CO}_{3}{ }^{2-}$. The water is of the sodium-bicarbonate type, and has a high $\mathrm{pH}=$ 9.8, mineralization of $193 \mathrm{mg} / \mathrm{l}$, and low temperature $\left(14^{\circ} \mathrm{C}\right)$; the concentration of chlorides is $15.17 \mathrm{mg} / \mathrm{l}$, silicon - $12.46 \mathrm{mg} / \mathrm{l}$, and fluorides $-1.27 \mathrm{mg} / \mathrm{l}$.

\section{Acknowledgements}

This work has been carried out in the framework of the National Science Program "Environmental Protection and Reduction of Risks of Adverse Events and Natural Disasters", approved by the Resolution of the Council of Ministers No. 577/17.08.2018 and supported by the Ministry of Education and Science (MES) of Bulgaria (Agreement No. D01-363/17.12.2020). The authors are grateful to Prof. Nikolay Stoyanov (University of Mining and Geology, Sofia) and Assoc. Prof. Zornitsa Cholakova (Sofia University) for critical reviews and comments.

\section{REFERENCES}

Chadha, D.K. 1999. A proposed new diagram for geochemical classification of natural waters and interpretation of chemical data. Hydrogeology Journal 7 (5), 431-439, https://doi. org/10.1007/s100400050216.

Dimitrova, R., Katzkov, N. 1990. Geologic map of the Republic of Bulgaria in scale 1:100 000, Velingrad map sheet. Committee on Geology, Company for Geophysical Surveys and Geological Mapping, Sofia.

Georgiev, M. 1991. Physical Geography of Bulgaria. Sofia University “St Kliment Ohridski” Publishing House, Sofia, 406 pp. (in Bulgarian).
Koleva, E., Peneva, R. 1990. Climate Guide. Precipitation in Bulgaria. Bulgarian Academy of Sciences Publishing House, Sofia, 169 pp. (in Bulgarian).

Klimov, I., Marinova, R, Marinova, A., Petrov, I., Valev, V. 2010a. Geologic map of Bulgaria in scale 1:50 000, Gotse Delchev map sheet. Bulgarian National Geological Survey, Sofia.

Klimov, I., Marinova, R., Marinova, A., Petrov, I., Valev, V. 2010b. Geologic map of Bulgaria in scale 1:50 000, Petrovo map sheet. Bulgarian National Geological Survey, Sofia.

Kozhoukharov, D., Marinova, R. 1991. Geologic map of the Republic of Bulgaria in scale 1:100 000, Gotse Delchev 
map sheet. Committee on Geology, Company for Geophysical Surveys and Geological Mapping, Sofia.

Kozhoukharov, D., Dimitrova, R., Katzkov, N. 1990. Geologic map of the Republic of Bulgaria in scale 1:100 000, Dospat map sheet. Committee on Geology, Company for Geophysical Surveys and Geological Mapping, Sofia.

Kyuchukova, M. 1983. Climate Guide of the Republic of Bulgaria. Volume 3. Air Temperature, Soil Temperature, Frost. Bulgarian Academy of Sciences Publishing House, Sofia, 440 pp. (in Bulgarian).

Li, X., Hao, W., Hui, Q., Yanyan, G. 2018. Groundwater Chemistry Regulated by Hydrochemical Processes and Geological Structures: A Case Study in Tongchuan, China. Water 10 (3), 1-16, https://doi.org/10.3390/w10030338.

Marinova, R. 1991. Geologic map of the Republic of Bulgaria in scale 1:100 000, Blagoevgrad map sheet. Committee on Geology, Company for Geophysical Surveys and Geological Mapping, Sofia.

Marinova, R., Zagorchev, I. 1990. Geologic map of the Republic of Bulgaria in scale 1:100 000, Razlog map sheet. Committee on Geology, Company for Geophysical Surveys and Geological Mapping, Sofia.

Marinova, R., Katzkov, N. 1990. Geologic map of the Republic of Bulgaria in scale 1:100 000, Belitsa map sheet. Committee on Geology, Company for Geophysical Surveys and Geological Mapping, Sofia.

Milovanov, P., Klimov, I., Petrov, I., Valev, V., Marinova, A., Sinnyovsky, D., Ichev, M., Ilieva, E. 2009a. Geologic map of Bulgaria in scale 1:50 000, Razlog map sheet. Bulgarian National Geological Survey, Sofia.

Milovanov, P., Petrov, I., Marinova, A., Valev, V., Klimov, I., Sinnyovsky, D., Ichev, M., Ilieva, E. 2009b. Geologic map of Bulgaria in scale 1:50 000, Bansko map sheet. Bulgarian National Geological Survey, Sofia.

Pentchev, P., Borisov, S., Velikov, B., Lakov, A., Spasov, K. 1990. Hydrogeology and the Fundamentals of Engineering Geology. Tehnika, Sofia, 342 pp. (in Bulgarian).

Petrov, P. 1964. Basic regularities in the occurrence of mineral waters in Bulgaria. Travaux sur la géologie de la Bulgarie, série Géologie ingénierie et hydrogéologie 3, 83-158 (in Bulgarian, with English abstract).

Piper, A.M. 1944. A graphic procedure in the geochemical interpretation of water analysis. Transactions American Geophysical Union 25 (6), 914-928, https://doi.org/10.1029/ TR025i006p00914.
Rajesh, R., Brindha, K., Murugan, R., Elango, L. 2011. Influence of hydrogeochemical processes on temporal changes in groundwater quality in a part of Nalgonda district, Andhra Pradesh, India. Environmental Earth Sciences 65 (4), 12031213, https://doi.org/10.1007/s12665-011-1368-2.

Sarov, S., Naydenov, K., Georgiev, N., Jelezarski, T., Georgieva, I., Ivanova, D., Popov, A., Markov, N. 2009a. Geologic map of Bulgaria in scale 1:50 000, Sarnitsa map sheet. Bulgarian National Geological Survey, Sofia.

Sarov, S., Naydenov, K., Georgiev, N., Jelezarski, T., Georgieva, I., Ivanova, D., Popov, A., Markov, N. 2009b. Geologic map of Bulgaria in scale 1:50 000, Dospat map sheet. Bulgarian National Geological Survey, Sofia.

Sarov, S., Voynova, E., Naydenov, K., Nikolov, D., Georgieva, I., Petrov, N., Markov, N., Marinova, R. 2009c. Geologic map of Bulgaria in scale 1:50 000, Velingrad map sheet. Bulgarian National Geological Survey, Sofia.

Sarov, S., Moskovski, S., Voynova, E., Jelezarski, T., Georgiev, N., Marinova, A., Nikolov, D., Georgieva, I., Markov, N. 2010a. Geologic map of Bulgaria in scale 1:50 000, Dobrinishte map sheet. Bulgarian National Geological Survey, Sofia.

Sarov, S., Moskovski, S., Voynova, E., Jelezarski, T., Nikolov, D., Georgieva, I., Marinova, A., Markov, N. 2010b. Geologic map of Bulgaria in scale 1:50 000, Hadzhidimovo map sheet. Bulgarian National Geological Survey, Sofia.

Sarov, S., Moskovski, S., Voynova, E., Jelezarski, T., Georgiev, N., Marinova, A., Nikolov, D., Georgieva, I., Markov, N. 2010c. Geologic map of Bulgaria in scale 1:50 000, Kovachevitsa map sheet. Bulgarian National Geological Survey, Sofia.

Sarov, S., Voynova, E., Nikolov, D., Georgieva, I., Nikolov, D., Marinova, A., Markov, N. 2010d. Geologic map of Bulgaria in scale 1:50 000, Tsvetino map sheet. Bulgarian National Geological Survey, Sofia.

Sarov, S., Moskovski, S., Jelezarski, T., Georgiev, N., Voynova, E., Nikolov, D., Georgieva, I., Markov, N. 2011a. Geologic map of Bulgaria in scale 1:50 000, Belitsa map sheet. Bulgarian National Geological Survey, Sofia.

Sarov, S., Voynova, E., Georgieva, I., Nikolov, D., Markov, N. 2011b. Geologic map of Bulgaria in scale 1:50 000, Yakoruda map sheet. Bulgarian National Geological Survey, Sofia.

Sarov, S., Voynova, E., Georgieva, I., Nikolov, D., Markov, N. 2011c. Geologic map of Bulgaria in scale 1:50 000, Rila Monastery map sheet. Bulgarian National Geological Survey, Sofia. 